\title{
Evidence on Nursing Administration Epistemology
}

\author{
Evidências sobre uma Epistemologia de Administração em Enfermagem \\ Evidencias sobre una Epistemología de la Administración en Enfermería
}

'Universidade Federal de São Paulo. São Paulo, São Paulo, Brazil.

How to cite this article: Meneses AS, Cunha ICKO. Evidence on Nursing Administration Epistemology. Rev Bras Enferm. 2020;73(Suppl 5):e20190275. doi: http://dx.doi.org/10.1590/0034-7167-2019-0275

Corresponding author:

Abel Silva de Meneses

E-mail: enfermeiro.meneses@gmail.com

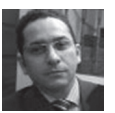

EDITOR IN CHIEF: Dulce Barbosa ASSOCIATE EDITOR: Alexandre Balsanelli

Submission: $06-26-2019$

Approval: 06-14-2020

\section{ABSTRACT}

Objective: Reflecting critically on the epistemological aspects of the of knowledge construction on Nursing Administration in Brazil. Methods: This is an article of theoretical reflection that aims to assess the epistemological aspects of the construction of knowledge about Nursing Administration. Results: The knowledge about Nursing Administration has a long way to go, as its epistemological repertoire is still timid. In addition, the lack of distinction of this knowledge in the communication of research products underestimates the production on Nursing Administration, as these products appear diluted in other areas of Nursing (care, research, and teaching). Final considerations: Due to the reflections, the need for new scientific evidence is highlighted, whose formulation of research questions can contribute to the delineation of phenomena that distinguish Nursing Administration as an area of research knowledge.

Descriptors: Nursing; Nursing Administration Research; Evidence-Based Nursing; Knowledge Bases; Espistemology.

\section{RESUMO}

Objetivo: Refletir criticamente sobre os aspectos epistemológicos da construção do saber sobre Administração em Enfermagem no Brasil. Métodos: Trata-se de um artigo de reflexão teórica que tem por objeto a apreciação dos aspectos epistemológicos da construção do saber sobre Administração em Enfermagem. Resultados: O conhecimento sobre Administração em Enfermagem tem um longo caminho a trilhar, pois seu repertório epistemológico ainda é tímido. Além disso, a falta de distinção desse saber na comunicação de produtos de pesquisa subestima a produção sobre Administração em Enfermagem, pois esses produtos aparecem diluídos em outras áreas da Enfermagem (assistência, pesquisa e ensino). Considerações finais: Em razão das reflexões, ressalta-se a necessidade de novas evidências científicas cuja formulação de perguntas de pesquisa possa contribuir para o delineamento de fenômenos que distingam a Administração em Enfermagem como área de conhecimento em pesquisa. Descritores: Enfermagem; Pesquisa em Administração de Enfermagem; Enfermagem Baseada em Evidências; Bases de Conhecimento; Epistemologia.

\section{RESUMEN}

Objetivo: reflexionar críticamente sobre los aspectos epistemológicos de la construcción del conocimiento sobre Administración en al ámbito de la Enfermería en Brasil. Métodos: Este es un artículo de reflexión teórica que tiene como objetivo evaluar los aspectos epistemológicos de la construcción del conocimiento sobre Administración en Enfermería. Resultados: El conocimiento sobre la Administración en Enfermería tiene un largo camino por recorrer, ya que su repertorio epistemológico aún es tímido. Además, la falta de distinción de este conocimiento en la comunicación de los productos de investigación subestima la producción sobre Administración en Enfermería, ya que estos productos parecen diluidos en otras áreas de la Enfermería (cuidado, investigación y enseñanza). Consideraciones finales: debido a las reflexiones, se destaca la necesidad de nuevas pruebas científicas, cuya formulación de preguntas de investigación puede contribuir a la delimitación de fenómenos que distinguen a la Administración en Enfermería como un área de conocimiento de investigación. Descriptores: Enfermería; Investigación en Administración de Enfermería; Enfermería Basada en la Evidencia; Bases del Conocimiento; Espistemología. 


\section{INTRODUCTION}

Nursing Administration (NA) has come a long way in its transformations throughout history, having Florence Nightingale's social contributions as the fundamental outsets of its scientific identity ${ }^{(1)}$.

Although the benchmark on the beginning of NA practices is commonly attributed to Florence Nightingale, we should also mention the Sisters of Charity of the Saint Vincent de Paul Company from Paris (founded in 1633), with whom Florence based her style of thinking about NA, when she was an intern at the Hôtel Dieu, occasion on which she made exquisite reflections on the management model practiced there: direction and reorganization of the hospital; individualization of beds; division of labor; time control; creation of regulations and work duties; supervision and direction of all care provided at the hospital ${ }^{(2-3)}$.

Therefore, it did not take long for Florence to reveal to the world the managerial thinking style of modern Nursing (Nightingale model) $)^{(3)}$, established through the publication of the book"Notes on matters affecting the health, efficiency, and hospital administration of the British Army" (1858), containing, among other things, statistical reports on the results of the management of a military hospital at the time of the Crimean War (1854). Certainly the first international evidence on an epistemology of $\mathrm{NA}^{(1)}$.

In Brazil, the epistemological antecedents on the practice of NA mention the productions dating from 1947 published in the journal "Anais de Enfermagem" [Brazilian Nursing Journal], however, they were translations of articles in English and would not configure their own identity to integrate the evidence of a properly Brazilian epistemology of $\mathrm{NA}^{(4)}$.

Nevertheless, there are other historical evidences about NA in Brazil and in the world, the object of this scientific production is circumscribed to the epistemological aspects of the construction of 'knowledge about NA' in Brazil, whose solidity depends especially on the creation of scientific communities that support the building process of that knowledge.

\section{OBJECTIVE}

To critically reflect upon the epistemological aspects of the of knowledge construction on Nursing Administration in Brazil.

\section{NURSING SCIENTIFIC COMMUNITY AND ITS CONTRIBUTIONS TO THE EPISTEMOLOGY OF NURSING ADMINISTRATION}

There is no doubt about the importance of the teaching staff for Brazilian graduate programs. This element plays a fundamental role both in the training of human resources for the scientific community with master's and doctorate degrees, and in the development of research products that meet the knowledge needs expressed by Nursing.

According to Nursing History scientists ${ }^{(5)}$, the training process of the nursing scientific community in Brazil has gone through five generations of nurse researchers, namely: the "pioneers" generation (1950-1960), the "self-taught" generation (1960-1970), the "academics" generation (1970-1980), the"systematic and collective production" generation (1990-2000) and the "researchers with international scientific production" generation (2000 onwards).
Considering the current scientific scenario, we are possibly in the sixth generation of nurse researchers, being considered the generation of "technological innovators".

With regard to NA, the first graduate research in the area emerged from the generation of self-taught Nursing researchers and dealt with the Ideological and Theoretical Bases of NA, whose pioneering work is the thesis defended by Glete de Alcântara in $1963^{(6)}$. Although it is important to demarcate its social space, NA needs to consolidate its identity in the academy, because although the academic discourse promotes this work process, its frequency and productivity history does not support this conviction, which seems to be restricted to the ideological domain ${ }^{(4,6-7)}$.

The symptoms of this scientific malnutrition are also felt by the international scientific community dedicated to NA and, in general, reflect negatively on the development of administrative work processes for nurses who tend to use applied research as a mechanism of advanced practice in solving managerial problems $s^{(8-9)}$.

Regarding the object of the present reflection, it could not be different, since the set of references cited therein demonstrates, rightly, the situation of this scientific panorama in Brazil, considering the concentration of old and polarized productions in a few scholars, which can limit the presentation of more in-depth formulations on the epistemology of NA. However, this risk must be assumed by the authors when considering these gaps as opportunities for Nursing.

So, what would be the aspect for which the NA has not sufficiently produced the interest of researchers to carry out innovative scientific investigations? Certainly, there are no precise and Cartesian formulations for something so complex, but the appraisals below may indicate some paths.

It seems that this phenomenon may be linked both to the timid interaction between nurses who share the same thinking style concerning $\mathrm{NA}^{(3)}$, and to the lack of scientific policies that encourage the production of research in groups and in networks, which seems to be confirmed given the small number of lines and research groups dedicated to the study of NA which, in addition to not following the progress of graduate programs, make up less than one-tenth of the total of research groups that bring together the nursing scientific community ${ }^{(6-7)}$.

Certainly, the social interaction among researchers would not be the only important variable to be dealt with in this phenomenon and also the promotion of spaces for intellectual discussion among specialists in NA, to provoke the proposition of programs for the development of advanced practices of NA that, among other solutions, will strengthen international and collaborative relations among research centers and NA graduate programs ${ }^{(7-8)}$.

This phenomenon can be explained according to the assumptions about collective thinking, which sees science as a product of cooperation among different groups and their styles of thinking ${ }^{(3)}$ and, sustained according to the forming attributes of the nursing scientific community, which are characterized by the "succession of generational groups, each inserted in a specific time and space and which, due to the concrete bonds they maintain among their members, present similarities regarding their training and scientific production, sharing a common historical and social destiny"(5).

Analyzing NA, in the same light, it seems that going through long paths until the appearance of generations of scientists dedicated to the study of this theme is still necessary. This can be illustrated 
from a bibliometric study whose result showed that, among 245 different scientists who guided research products on NA in the master's and doctorate degrees identified in five decades, only $2.9 \%$ were regular supervisors of research on NA in relation to the others, with $57.1 \%$ only advising a single research product in this area ${ }^{(10)}$.

Out of curiosity, a study has analyzed the curriculum ${ }^{1}$ of 245 supervisors available on the website of the National Council for Scientific and Technological Development (CNPq), and stated it was observed that the supervisors moved both in the production of research involving the Nursing Management Work Process, and in the production of research involving other Nursing Work Processes (assisting, researching, teaching and participating politically $)^{(10)}$.

It is also noteworthy that many research products whose object of study dealt with NA often appeared linked to other areas of Nursing, which would probably interfere in bibliometric analysis on related knowledge production. There is a gap that needs attention from Nursing scientists ${ }^{(10)}$.

This link to the care processes seems to result from attempts to minimize the dichotomous view on management and care, supported by an ideological conception that reverberates the social division of Nursing work (lady nurse and nurse), according to Nightingale. And the assumptions of the classical and bureaucratic theories of administration, which still consider the Nursing Management Work Process far from direct and technical care, when in fact its product is to provide conditions for care to be carried out efficiently and effectively ${ }^{(1-2,9)}$. This dichotomy tends to decline under complex thinking paradigms and with nurses occupying jobs in the strategic organization chart of healthcare organizations, whose experimentation with executive management processes sets up potential opportunities for formulating new hypotheses about $N A^{(9,11)}$.

Another issue that deserves attention, and that can be considered a vulnerability in the construction of knowledge about NA, seems to be the lack of successions of scientists dedicated to this area. This makes it pertinent to revisit Tilghman's statement in Nassi-Calò's reflections on scientific communication in academic theses and dissertations, highlighting that "[...] the only way you can assess it whether the graduates of the program became successful scientists. If they do, you've done a good job. If they haven't, you haven't"(12).

In the same line of thought, among the $\mathbf{5 9 6}$ graduates from graduate programs identified in the bibliometric study mentioned $^{(10)}$, only $50(8.4 \%)$ continued as advisors in the NA area, but, in fact, only four $(0,5 \%)$ seem to have been successful in the development of research products linked to the themes studied with their advisors, which may signal weaknesses in cultivating knowledge about NA and, consequently, the construction of their epistemic repertoire.

Except for the epistemological point of view, gaps in knowledge represent an opportunity for those who wish to communicate results of research on NA, but their success depends on the presentation of evidence that is based on sophisticated research

1 These curriculums were assessed through Lattes platform - http://lattes. cnpq.br/ - which is a Brazilian national database for the production and curriculum of scholars. designs, including those dedicated to hypothesis testing. Bearing in mind that the prevalence of the available scientific repertoire is of descriptive studies that gave their share of contribution to the $\mathrm{NA}$, as they indicated saturation of slightly varied methods ${ }^{(7,10)}$.

\section{EPISTEMOLOGICAL ASPECTS OF NURSING ADMINISTRATION}

Drawing a parallel between the progression of knowledge about Nursing and NA is not difficult to be observed, due to the phenomena presented, that it endures in a "moment of transition between the use of administration principles as a central issue in the area and some initiatives of the development process of nursing care management/administration theories"(7)

Nevertheless, it should be noted that when consulting the Brazilian scientific production in the area, there is still a linguistic shortage regarding the production of concepts about this knowledge, something indispensable for understanding the phenomena of Nursing Administration.

This gap is so evident that a Brazilian Nursing epistemologist declared the need for repeated experiments of epistemological methodology in the analysis of the production of nursing knowledge, emphasizing that:

the scientific construction culture lacks validation exercises, which can only be achieved in the field of experimentation and under requirements of proof or counterproof. Changing nomenclature and terminology does not always mean that things change. Research and scientific construction can change a lot, can shake old concepts and can reveal at least "the invisible in the visible"(13).

In fact, a thorough search of all available databases has shown that, except for isolated initiatives to present some knowledge configuration about $\mathrm{NA}^{(14-15)}$, nothing else is relevant in the international scenario on epistemology in this field of knowledge, except for a brief reflection warning about the need to strengthen international relations among research centers on NA based on the epistemological justification that only confirms this invisibility ${ }^{(8)}$.

Before the imperative need to boost scientific knowledge about NA - until we reach an epistemic repertoire capable of designating its own theoretical formulations - its theoretical view shares from other knowledge, in view of the conceptual formulations that can handle the Nursing Management Work Process.

In a 1988 publication ${ }^{(16)}$, international nursing epistemologists defined nursing epistemology as the study of the origin of its knowledge, structures, and methods; patterns of knowledge created and used by peers; as well as criteria used to validate their knowledge. In this perspective, the epistemology of NA has as its object of investigation the 'knowledge about NA', which can be understood when focused on the plan of scientific knowledge construction about this knowledge.

In the epistemological domain, Nursing knowledge in Brazil began its path as a solid field in the context of graduate Nursing programs created in the 1970s, progressing its knowledge repertoire over the first three generations of Nursing scientists, until it reached its sovereignty as a knowledge area along with CNPq and Coordination for the Improvement of Higher Education Personnel (CAPES), respectively in 1986 and $2007^{(5)}$. 
Therefore, the 'knowledge about NA' in Brazil has its roots in the "self-taught" Nursing researchers generation ${ }^{(5)}$, based on the thesis written by Glete de Alcântara, already mentioned, on 'Labor Market and Fields of Work' ${ }^{\prime(6)}$, potentially, the initial study for epistemological discussion on Nursing Management.

From then on, other research products about NA emerged over the other generations of Brazilian Nursing scientists, until there was a scientific repertoire capable of initiating reflections on the epistemology of knowledge in this area.

Considering the assumptions of nursing epistemology, the first contribution on NA epistemology in Brazil that analyzed "knowledge patterns created"(16) is evidenced in the "lines of research and nursing priorities"(17), with the distinction of this knowledge in the "Management of Health and Nursing Services" line which involves studies on ideological and philosophical theories and principles of health and nursing administration, as well as the management of the structure, process, and results of health and nursing care.

When we turn our attention to the subject of "lines of research and nursing priorities" in another research product ${ }^{(13)}$, a Brazilian Nursing epistemologist stated that she had encountered difficulties in the workgroup on lines of research regarding the meaning of "Organizational" category, which contains the line on "Management of Health and Nursing Services", showing complexity in tuning the NA standards in the epistemological plan.

Although the 'knowledge about NA' already had its distinction among Nursing knowledge products, the aforementioned epistemologist urged researchers on the need to subject lines of research to experimentation, "since the purpose is not to reach the truth, only the reliable results, and until there are answers from the cultivation of the lines of research"(17).

In search of these"answers from the cultivation of lines of research" and anchored by the foundations about epistemological constructs of the "subject-object relationship" presented by the epistemologist in evidence ${ }^{(17)}, 34$ volumes of the "Catalog of Theses and Dissertations" were appreciated, available at the Center of Studies and Research in Nursing (CEPEn) of the Brazilian Nursing Association (ABEn), which aim to identify "knowledge standards created"(6,16).

This appreciation of the experimentation and cultivation of 'knowledge about NA' by Brazilian nurses in the context of graduate studies stricto sensu illuminated reflections on the scientific configuration of the knowledge bases produced in just over half a century (1963-2016) of research. In this way, revealing evidence about the first products of an NA epistemology capable of representing, until then, the state of the art of this production and sustaining its own concepts, as demonstrated in the schematic perspective of Figure 1.
The schematic representation of Figure 1 expresses the construction of 'knowledge about NA' in Brazil outlined according to the assumptions of the epistemology of NA in three domains configured as follows: ' Knowledge Repertoire,' 'Theoretical Appreciation' and 'Enunciation of Units of Knowledge'(16).

The domain' Knowledge Repertoire' portrays the context of the first epistemological distinction of NA in Brazil, being through the enunciation of the concept "Management of Health and Nursing Services", identity nature, and differences in relation to other concepts of the same tree ${ }^{(17)}$. Based on this ontology, the Brazilian NA now has a reference object to declare research formulations with the awareness of this concept in the constriction of its knowledge repertoire $^{(16)}$.

The domain 'Theoretical Appreciation', on the other hand, represents the mechanism used in the identification of phenomena arising 
from 'knowledge about NA', which must happen in a subject-object relationship, since from the point of view of scientific research:

knowledge arises from the Subject's attempts (cognoscente consciousness) to define the Object (things or ideas) or, according to its purposes, so that it can name the objective aspects (facts or phenomena) of interest. The nature of knowledge depends on the relationship between the two elements. The Subject's function is to apprehend the Object or, better to say, what results from it. The object's function is to be apprehended by the Subject. However, as it is in the nature of knowledge that the two elements remain separate, then it is assumed that, on the level of knowledge, the Subject apprehends an image of the Object. Thus, in its condition of 'image', the gnoseological material seems as if occupying a third sphere (that of 'image') intermediating the two already mentioned. And since the sphere of 'image' provides a possible approximation between the two elements (Subject and Object), it is understood that the result of knowledge corresponds, effectively, to an approximate truth ${ }^{(13)}$.

Considering that the epistemology of NA has as its object of exploration the 'knowledge about NA', and that in epistemology the conception of truth is translated into language and terminology, the great challenge of this reflection is to make the image of this object present to the senses and understandable to human intelligence, as it was intended to do with the presentation of the domain'Enunciation of Units of Knowledge'. This domain is part of the "Structure of Knowledge on Nursing Administration", which is composed by three large groups of representation of NA hierarchically constituted, "Ideological and Theoretical Bases","Intervention Methods" and "Resource Management Practices". These, in turn, concentrate their respective "Units of Knowledge" according to the epistemological pertinence identified in the observed phenomena.

From an epistemological point of view, the units of knowledge configure an identity profile about how the phenomena of Nursing Management may be recognized or associated with new phenomena, or even instead of configuring themselves as responses about the phenomena, configuring themselves as objects of questioning about NA.

\section{Contributions to the Nursing field}

Referring to the Nursing epistemological assumptions knowledge standards created and used by their peers ${ }^{(16)}$ - the epistemological representation of 'knowing about NA', presented in Figure 1, reflects the universe of knowledge about Nursing Management built over more than half a century of research, whose conception was almost always reactive to the social scenario experienced and, therefore, in a collective sense, constituting the ontological and epistemological foundations of this area (10).

For that purpose, obviously, the main contribution of this reflection is that, in the image sphere, the distinction of the units of knowledge of 'knowing about NA' has an effect as a basis of thinking to contemplate the Nursing Management and, maybe, in the future to build new epistemological evidence that can direct the proposition of theories about the phenomena of Nursing Administration.

\section{Study limitations}

The scarcity of regular scientific productivity, little diversified and concentrated in rare scholars, presents itself as the variable that can limit the presentation of more in-depth formulations on the object of this reflection.

\section{FINAL CONSIDERATIONS}

Undoubtedly, we have made progress in research activities with nuclei and groups of researchers engaged in the cultivation of lines of research on NA, but we still lack the support of more in-depth knowledge and the effectiveness of research results that are expressed by robust evidence and by transformations in NA practices.

Certainly, the configuration of the 'knowledge about NA' will produce some effect, which is the understanding and the epistemological scope of this knowledge or critical thinking about Nursing Management, in addition to being an object of appreciation for future reflections.

After all, the objective of all science is to coordinate our experiences and elevate them to a logical and explainable system and, unquestionably, to an epistemological immersion in the 'knowledge about NA' that presents a description of the terms of the archetype scheme of that knowledge and that can say better about what is thought to be NA, under the view of Brazilian nursing scientists.

\section{REFERENCES}

1. Nightingale F. Notes on matters affecting the health, efficiency and hospital administration of the British army founded chiefly on the experience of the late war. Presented by request to the Secretary of State for War [Internet] London (UK): Harrison \& Sons; 1858 [cited 2020 Oct 15]. 1.075 p. Available from: https://archive.org/details/b20387118/page/n137/mode/2up.

2. Padilha MICS, Mancia JR. [Florence Nightingale and charity sisters: revisiting the history]. Rev Bras Enferm. 2005;58(6):723-6. doi: 10.1590/ S0034-71672005000600018.0 Portuguese.

3. Barbosa L, Pereira Neto A. Ludwik Fleck (1896-1961) and knowledge translation: considerations about the genealogy of a concept. Saúde Debate 2017;41(esp):317-29. doi: 10.1590/0103-11042017S23.

4. Martins EG, Sanna MC. [The nursing administration scientific publications in Brasil since 1947 until 1972]. Rev Bras Enferm. 2005;58(2):235-9. doi: 10.1590/S0034-71672005000200022 Portuguese.

5. Salles EB, Barreira IA. [The development of nursing scientific community in Brazil]. Texto Contexto Enferm. 2010;19(1):137-46. doi: 10.1590/ S0104-07072010000100016 Portuguese. 
6. Meneses AS, Sanna MC. Structure of Knowledge about Nursing Administration in Brazilian Graduate Programs. Texto \& contexto enferm. 2016;25(1):e0380015. doi: 10.1590/0104-0707201500000380015

7. Erdman AL, Mello ALF, Sndrade SR, Klock P. [Functionality of the nursing, management and administration research groups]. Rev RENE [Internet] 2010 [cited 2020 Fev 20];11(2):19-26. Available from: http://repositorio.ufc.br/bitstream/riufc/14661/1/2010_art_alerdmann.pdf Portuguese.

8. Dallaire C. International Collaboration and Graduate Programs in Nursing Administration. Rev Esc Enferm USP. 2011;45(esp):1537-38. doi: $10.1590 /$ S0080-62342011000700001

9. Copelli FHS, Oliveira RJT, Oliveira CMS, Meirelles BHS, Mello ALSF, Magalhaes ALP. Complex Thinking and its Impact on Nursing and Health Management. Aquichan. 2016;16(4):501-12. doi: 10.5294/aqui.2016.16.4.8

10. Meneses AS. Analysis of the scientific production of Brazilian nurses on nursing administration in the context of graduate programs stricto sensu: a historical approach (1963-2011). [Dissertação] [Internet]. [São Paulo]: Universidade Federal de São Paulo; 2014.135 p. doi: 10.13140/RG.2.1.2991.5281

11. Molin TD, Oliveira JLC, Tonini NS, Oliveira RM, Souza RF, Anchieta DW, et al. Proactive behavior of hospital nurses: comparison between jobs. Cogitare Enferm. 2019;24:e58174. doi: 10.5380/ce.v24i0.58174

12. Nassi-Calò L. Theses and dissertations: pros and cons of the traditional and alternative formats. SciELO Perspect[Internet] 2016 [cited 2019 Jun 24];29(23):[07 telas]. Available from: http://blog.scielo.org/blog/2016/08/24/ teses-e-dissertacoes-pros-e-contras-dos-formatos-tradicional-e-alternativo/

13. Carvalho V. About the objectivity in the subject-object relationship in the image's plan or in the instrumental/organizational scope: a point of view for the nursing research. Esc Anna Nery. 2008;12(2):334-40. doi: 10.1590/S1414-81452008000200021

14. Biron $A D$, Richer $M C$, Ezer $\mathrm{H}$. A conceptual framework contributing to nursing administration and research. J Nurs Manag. 2007;15(2):188-196. doi:10.1111/j.1365-2834.2007.00661.x

15. Wang C-H, Lee Y-D, Chou H-L, Kuo J-H. Mapping the intellectual structure of nursing management. IJMO. 2014;4(2):163-6. doi: 10.7763/ IJMO.2014.V4.366

16. Schultz PR, Meleis Al. Nursing epistemology: traditions, insights, questions. Image J Nurs Sch. 1988;20(4):217-21. doi:10.1111/j.1547-5069.1988.tb00080

17. Carvalho V. [Research lines and priorities of nursing: proposal with gnoseological distinction for the grouping of the graduate scientific production in nursing]. Esc. Anna Nery [Internet]. 2002 [cited 2019 Jan 24];6(1):145-54. Available from: https://s3-sa-east-1.amazonaws.com/ publisher.gn1.com.br/eean.edu.br/pdf/v6n1a16.pdf Portuguese. 


\section{Endnotes}

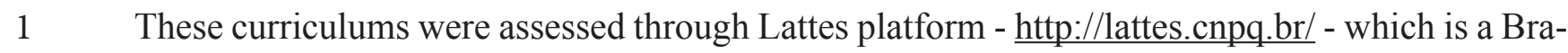
zilian national database for the production and curriculum of scholars. 